\title{
中京地域で発生する長周期地震動に対する堆積盆地及び付加体の影響 THE EFFECT OF SEDIMENTARY BASINS AND ACCRETIONARY WEDGE ON LONG PERIOD GROUND MOTIONS IN CHUKYO AREA
}

\author{
山田沙代*, 平井 敬**, 福和伸夫*** \\ Sayo YAMADA, Takashi HIRAI and Nobuo FUKUWA
}

\begin{abstract}
This study clarifies the effect of the sedimentary basins and accretionary wedge to the long-period ground motion using the seismic ground motion records and the finite difference analysis. The effect of both the sedimentary basins on the wave propagation path and the sedimentary basin beneath the site are revealed. Each sedimentary basin on the wave propagation path affects the long-period seismic wave, respectively. The seismic wave is strongly amplified by the sedimentary basin if the seismic source locates at particular direction. These phenomena are examined by the finite difference analysis using a simple soil structure model. In addition, the behavior similar to the result of numerical analysis is shown by the study using the seismic ground motion records.
\end{abstract}

Keywords : Long-period ground motion, Seismic source location, Propagation path, Sedimentary basin, Reciprocity theorem, Finite difference method 長周期地震動，震源位置，伝播経路，堆積盆地構造，相反定理，有限差分法

\section{1. はじめに}

近年，巨大地震による長周期・長時間地震動が懸念されている. 特に石油タンクのスロッシング現象や，大規模堆積盆地上の高層建 物の共振応答が問題となっており，伝播経路特性及び，堆積盆地内 の地震動増幅特性を適切に把握することの重要性が増している.

地震動には, 震源, 伝播経路, サイト増幅特性の 3 つがそれぞれ 影響を与える。

伝播経路特性に影響を与えるものの 1 つに付加体がある. 付加体 が地震波に与える影響は数多く検討されており，付加体が表面波を 強く励起し, 継続時間を延ばし, 付加体に沿って地震波を誘導する 効果 ${ }^{1)}$ や, 震源の深さ・位置によって地震動に及ぼす影響が異なる こと 2),3) が示されている. 一方, 筆者ら ${ }^{4)}$ は, 陸域の伝播経路特性 に着目し，観測記録と有限差分法を用いた解析両面から，新潟堆積 盆地直下での地震では，中京地域へ向かう地震動の継続時間が増大 し, 震源の位置によっては特定の周期帯の振幅が大きくなることを 示した.

一方，サイト増幅特性については，地点固有のものと考えられて きたが, 堆積盆地上の地点においては地震によって震動特性が変動 することが指摘されている例えば 5), 6), 7),8)，これは不整形な堆積盆地に 対する地震波の入射方向及び，実体波か表面波といった地震波の種 類に影響を受けると考えられ，堆積盆地に横から入射する表面波に おいて顕著であることから, 長周期地震動を考える際には重要な要 素となる，そこで本研究では，「サイト増幅特性」の代わりに，観測
点位置と堆積盆地形状によって生み出される増幅的干渉効果 (以下, 震源位置依存サイト・堆積盆地干涉効果) について検討を行う. 既 報 4)では, 新潟県中越地震の際に関東平野内で長周期地震動が観測 された原因の 1 つとして, 関東平野北西部における盆地端生成表面 波の励起と, その表面波の平野中心部一の誘導・停滞について指摘 した文献 9) を陸域の伝播経路特性の一つとして挙げた。しかし, 本 研究の定義では文献 ${ }^{9)}$ のような, 長周期地震動が観測された関東平 野自体が長周期地震動を増幅する要素となった事象は, 震源位置依 存サイト・堆積盆地干渉効果に分類される.

本研究では, 地震時に中京地域の堆積盆地上の地点で観測される 地盤震動特性の評価を目標とし, 特に震源位置に着目して, 震源位 置依存サイト・堆積盆地干渉効果について基礎的な検討を行った. まず，中京地域の堆積盆地上の地点での上記 2 つの効果を，グリー ン関数の相反定理を用いた有限差分法による解析により検討した. 次に，地震波の振幅が特に大きくなった震源方位について，地震波 の伝播性状からその原因を考察した。ささに，振幅が大きくなる原 因について, 単純な 2 層地盤モデルを用いた解析を行った。最後に, 中京地域の地震動観測記録を用いて，岩盤観測点との応答スペクト ル比を算出することにより，中京地域の堆積盆地での地震動増幅の 震源位置依存性を検討し, 解析結果を踏まえて考察を行った。なお, 本論文で有限差分法による解析の対象とする周期帯は，おおむね周 期 $3 \mathrm{~s}$ 以上の成分とする，また，既報 ${ }^{4)}$ では，新潟地方の地震で伝播 経路の影響がレイリー波に顕著に認められたので, 本論文ではレイ

\footnotetext{
* 前 名古屋大学大学院環境学研究科 修士 (工学) (現 清水建設)

** 名古屋大学大学院環境学研究科 助教 - 博士 (工学)

*** 名古屋大学減災連携研究センター 教授. 工博
}

Former Grad. School of Environmental Studies, Nagoya Univ., M. Eng. (Shimizu Corporation in present) Assist. Prof., Grad. School of Environmental Studies, Nagoya Univ., Dr. Eng. Prof., Disaster Mitigation Research Center, Nagoya Univ., Dr. Eng. 
リー波に着目してラディアル成分のみの検討を行う。

\section{3 次元有限差分法に基づく地震動の震源位置依存性の検討}

\section{1 計算モデルと検討対象とした観測点}

地震動の震源位置依存性を検討するため, グリーン関数の相反定 理を用いた有限差分法により, 中京地域の堆積盆地上の複数地点で, 数多くの震源に対する地震動を計算する.

図 1 に, 計算に使用した地盤構造の領域と $V_{\mathrm{S}}=3200 \mathrm{~m} / \mathrm{s}$ 層上面深 さ分布を示す，用いた地盤構造モデルは，長周期地震動予測地図 ${ }^{10)}$ の作成に用いられたものである. 表 1 に各層の物性值を, 図 2 に中 京地域の堆積盆地の地震基盤深さと検討地点位置を示す. 検討地点 は，超高層建物が集中する名古屋駅，埋立地盤上の水上出張所，製 造業が集積している刈谷市とした. 図 3 に, 長周期地震動予測地図 10)の地盤モデルを用いて重複反射理論により算出した増幅スペク トルを示す. 各観測点の卓越周期は $3.9 \mathrm{~s}, 4.4 \mathrm{~s}, 4.0 \mathrm{~s}$ である.これら の地点について, 新潟堆積盆地, 付加体, 大阪平野を含む領域での 計算を行った. 3 観測点の計算には, 長周期地震動予測地図 ${ }^{10)}$ の地 下構造をそのまま使用したモデル (以下，モデル 1) に加え，伝播経 路特性の影響を除くために, 中京地域の堆積盆地以外の $V_{\mathrm{S}}=3200$ $\mathrm{m} / \mathrm{s}$ 層 (表 1 の第 14 層) 以浅の層を, $V_{\mathrm{S}}=3200 \mathrm{~m} / \mathrm{s}$ 層の物性值とした モデル (以下，モデル 2) を用いた. 加えて, 名古屋駅地点について は, 堆積盆地内の $V_{\mathrm{S}}=3200 \mathrm{~m} / \mathrm{s}$ 層以浅の層を, $V_{\mathrm{S}}=3200 \mathrm{~m} / \mathrm{s}$ 層の物 性值としたモデル (以下，モデル 3)，全ての $V_{\mathrm{S}}=3200 \mathrm{~m} / \mathrm{s}$ 層以浅の 層を, $V_{\mathrm{S}}=3200 \mathrm{~m} / \mathrm{s}$ 層の物性值としたモデル (以下，モデル 4) につ いても計算した. 以上のモデル概要を表 2 に示す. また, 各モデル において水上出張所を通る北から東回りの方位角 $335^{\circ}$ の測線の断 面図を図 4 示す.

用いた解析手法と震源は, 既報 ${ }^{4)}$ と同一である. 以下にその概要 を示す，差分解析には, Graves の食違い格子を用いる方法 ${ }^{11)}$ と Levander の 4 次差分による定式化 ${ }^{12)}$ を用いた。 また，格子形状は， 地表から深さ $7 \mathrm{~km}$ までは一辺 $200 \mathrm{~m}$, それ以深は一辺 $600 \mathrm{~m}$ の立方 体形とした. 1 波長を 5 格子以上で表現し, 解析の有効周期は $2.85 \mathrm{~s}$ 以上である。梁さ $7 \mathrm{~km}$ における境界処理には, Aoi and Fujiwara によ る不連続格子の接続方法 ${ }^{13)}$ を用いた。計算領域端部には, Clayton and Engquistによる無反射境界条件 ${ }^{14)}$ と，厚さ $12 \mathrm{~km} の$ Cerjan et al. によるエネルギー吸収境界条件 $\left.{ }^{15}\right)$ を併せて用いた。 Q 值は長周期地 震動予測地図の作成に用いられた地下構造モデル ${ }^{10)}$ の Qs 值を振動 数に比例するものとしてモデル化し, 表 1 には周期 $5 \mathrm{~s}$ での值を記載 した.

震源は, 図 1 の計算領域で $1 \mathrm{~km}$ 間隔の格子状に想定し，各点での 震源に対して地震動を算定した。震源メカニズムは, 既報 ${ }^{4)}$ との比 較を可能に寸るため, 新潟付近で発生しやすいメカニズムである傾 斜 $45^{\circ}$ ，滑り角 $90^{\circ}$ とし，観測地点に対する震源の放射特性を統一 するため, 観測地点からの震源の方位角を走向とした. 震源深さも 既報 4 ) と同様に表面波が成長しやすく伝播経路特性の影響を受けや すい $10 \mathrm{~km}$ とし, 地震モーメントは $9.3 \times 10^{18} \mathrm{~N} \mathrm{~m}\left(M_{\mathrm{W}}=6.6\right.$ 相当 $)$ と 設定した。コーナー振動数は Boore による円形クラックを仮定した 統計的グリーン関数のスペクトル作成法 ${ }^{16)}$ を参考に算出した。 そ の際, 応力降下量は全ての地震に対して $3.0 \mathrm{MPa}$ とした. 本検討で は地震動の完全な再現は目的としておらず，地震動の伝播経路特性
表 1 地盤構造モデル ${ }^{10)}$ の各層の物性値

\begin{tabular}{|c|c|c|c|c|c|}
\hline 層番号 & $\begin{array}{c}V_{\mathrm{S}} \\
{[\mathrm{km} / \mathrm{s}]}\end{array}$ & $\begin{array}{c}V_{\mathrm{P}} \\
{[\mathrm{km} / \mathrm{s}]}\end{array}$ & $\begin{array}{c}\text { 密度 } \\
{\left[\mathrm{kg} / \mathrm{m}^{3}\right]}\end{array}$ & $\begin{array}{c}\mathrm{Q} \text { 值 } \\
\text { (周期 } 5 \mathrm{~s} \text { ) }\end{array}$ & 備考 \\
\hline 1 & 0.35 & 1.70 & 1800 & 28 & \\
\hline 2 & 0.50 & 1.80 & 1950 & 40 & \\
\hline 3 & 0.60 & 2.00 & 2000 & 48 & \\
\hline 4 & 0.70 & 2.10 & 2050 & 56 & \\
\hline 5 & 0.80 & 2.20 & 2070 & 64 & \\
\hline 6 & 0.90 & 2.30 & 2100 & 72 & \\
\hline 7 & 1.00 & 2.40 & 2150 & 80 & 付加体を含む \\
\hline 8 & 1.30 & 2.70 & 2200 & 104 & \\
\hline 9 & 1.50 & 3.00 & 2250 & 120 & \\
\hline 10 & 1.70 & 3.20 & 2300 & 136 & \\
\hline 11 & 2.00 & 3.50 & 2350 & 160 & \\
\hline 12 & 2.40 & 4.20 & 2450 & 160 & \\
\hline 13 & 2.90 & 5.00 & 2600 & 160 & 地震基盤(近畿圈) \\
\hline 14 & 3.20 & 5.50 & 2650 & 160 & 地震基盤(上部地殼第 1 層) \\
\hline 15 & 3.40 & 5.80 & 2700 & 160 & 上部地款第 2 層 \\
\hline 16 & 3.80 & 6.40 & 2800 & 160 & 下部地殼 \\
\hline 17 & 4.50 & 7.50 & 3200 & 200 & マントル \\
\hline 18 & 2.90 & 5.00 & 2400 & 80 & 海洋性地殼第 2 層(フイリピン海プレート) \\
\hline 19 & 4.00 & 6.80 & 2900 & 120 & 海洋性地殼第 3 層(フイリピン海プレート) \\
\hline 20 & 4.70 & 8.00 & 3200 & 200 & 海洋性マントル(フィリピン海プレート) \\
\hline 21 & 2.80 & 5.40 & 2600 & 80 & 海洋性地殼第 2 層(太平洋プレート) \\
\hline 22 & 3.50 & 6.50 & 2800 & 120 & 海洋性地殼第 3 層(太平洋プレート) \\
\hline 23 & 4.60 & 8.10 & 3400 & 200 & 海洋性マントル(太平洋プレート) \\
\hline
\end{tabular}

表 2 地盤モデル概要

\begin{tabular}{cc}
\hline モデル名 & 概要 \\
\hline モデル 1 & 長周期地震動予測地図のモデル ${ }^{10)}$ をそのまま使用 \\
モデル 2 & 伝播経路特性を岩盤※としたもの \\
モデル 3 & 中京地域の堆積盆地を岩盤※としたもの \\
モデル 4 & 全て岩盤※としたもの \\
\hline ※“岩盤”は $V_{\mathrm{S}}=3200 \mathrm{~m} / \mathrm{s}$ 層の物性值とする
\end{tabular}

及び観測点の位置する堆積盆地の特性に着目しているため, 震源は 全て点震源とし, 震源時間関数は図 5 に示寸ものを用いた。この震

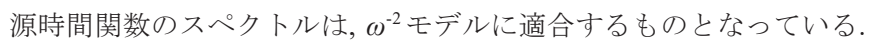
地震動波形には, 解析の有効周期を考慮し, 周期 $2.85 \sim 20 \mathrm{~s}$ のバン ドパスフィルターを作用させた．観測点となる加力点での $x$ 方向の 加力については周囲の $v_{x}$ 評価点 4 点, $y$ 方向の加力については周囲の $v_{y}$ 評価点 4 点に重み付きで分配した. ただし, $z$ 方向の加力にあたっ ては $v_{z}$ 評価点が地表から半格子分下にあるため, その深さでの加力 とした. 震源となる受振点については, 周囲 8 点での応力を重み付 き平均し, 応力一歪関係式により歪の值を計算した。

\section{2 解析結果}

まず, 2.2.1 2.2.3 において, モデル 1 の計算結果について示す.

\subsection{1 速度波形}

図 6 に, 深さ $10 \mathrm{~km}$ で水平方向に $1 \mathrm{~km}$ 毎に設定した震源で地震が 起きた際に各観測点で得られるラディアル方向の地震動速度波形を 示す. 白丸印の点の震源による々地点の地震動を示したものである. 振幅及び継続時間のスケールは統一してあり, 距離減衰補正は行っ ていない.

図 6 から, 各観測点において速度波形の分布の特徵がそれぞれ異 なっているのが分かる. 名古屋駅では, 中京地域の南側に震源があ る際に継続時間が長くなっている (図 6 (a) 中の白色実線で囲んだ 領域)．また，付加体の南部に位置する震源では速度振幅の大きい 時間が長く続いている (図6 (a) の白色破線で囲んだ領域) . 水上出 張所では，北側の震源で振幅の大きな地震動が長い時間継続してい るのが特徽的である (図 6 (b) 中の白色実線で囲んだ領域). 刈谷市 役所では, 震源方位による地震動の差はあまり目立たないが, 他の 


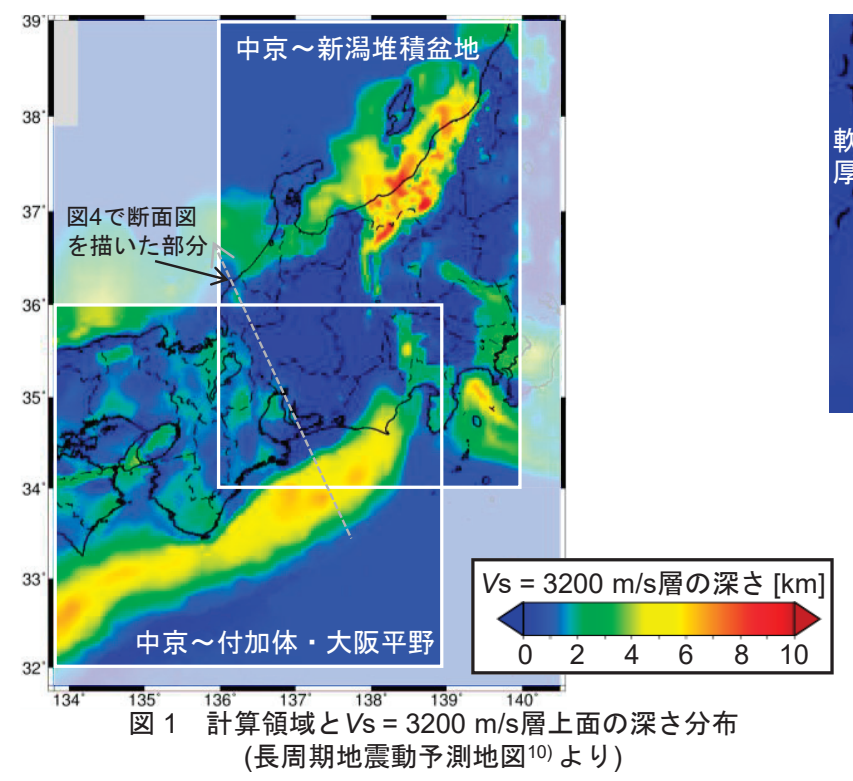

2 観測点と比較して付加体下の震源による地震動の振幅が大きく, 継続時間が長くなっている (図 6 (c) 中の白色破線で囲んだ領域).

\subsection{2 継続時間}

図 7 に, 継続時間とラディアル成分の周期別の速度応答スペクト ル (固有周期幅 $1 \mathrm{~s}$ の区間の平均値) を示す. 継続時間は, 速度振幅 の最大值の $10 \%$ を最初に超える時刻から最後に下回る時刻までの時 間とした. 図 7 の継続時間分布から, 各観測点に共通して, 新潟堆 積盆地の北側 $(\mathrm{A})$, 富山県沖の堆積盆地の北側 $(\mathrm{B})$ ，付加体の南側 (C) , 大阪平野の西側 (D) に, 継続時間が長くなる領域が存在する ことが分かる．既報 4)でも述べたとおり，伝播経路上の堆積盆地内 に閉じ込められた地震動のエネルギーが時間をかけて堆積盆地外 漏れ出ることから，伝播経路上の堆積盆地には，地震動の継続時間 を延ばす効果があると考えられる。ささに，各観測点において中京 地域の堆積盆地を地震波が長い距離通過する方向で継続時間が長く なっている (図 7 中の黒色実線で囲んだ領域)。これは, 中京地域の 堆積盆地への地震波の入射の後, 表面波の分散現象により継続時間 が延びたためと考えられる。

\subsection{3 各周期帯における速度応答スペクトルの平均值分布}

図 7 のラディアル方向の周期別の速度応答スペクトル (固有周期 $0.01 \mathrm{~s}$ 刻みで算出, 固有周期幅 $1 \mathrm{~s}$ の区間の平均值) は, 震央距離 300 $\mathrm{km}$ を基準として震央距離の平方根で距離補正を施した. 図 7 の応答 スペクトルの周期別の平均值分布から，観測点ごとに各周期帯域に おける応答スペクトルの值が異なった分布をしていることが分かる。 各観測点に共通して, 図 2 に示寸四日市沖の軟弱で減衰の大きな層 が厚く堆積しているところを通過する方向において，応答スペクト ルの值が小さくなっている (図 7 中の白色実線で囲んだ領域).これ は, 周期 $5 \mathrm{~s}$ より長周期において顕著である. 水上出張所では，周期 $3 \sim 6 \mathrm{~s}$ において北側の震源における応答スペクトルの值が顕著に大 きくなっている (図7 (b) 中の黒色破線で囲んだ領域)，それに加え， 長野県北や群馬県, 石川県のあたりで周りより值が大きくなる領域 がある (図 7 (b) 中の黒色実線で囲んだ領域) 。これは, 震源位置依 存サイト・堆積盆地干涉効果により北側の地震動が大きくなったと
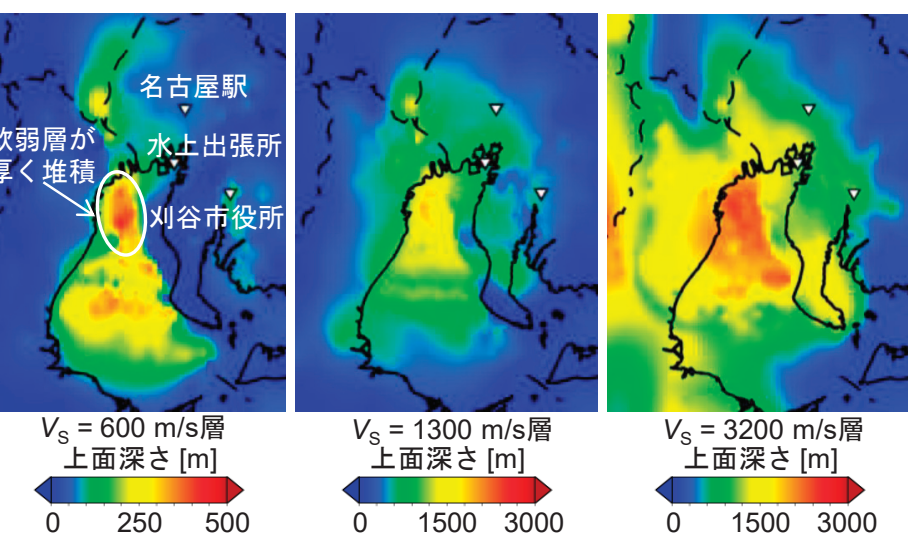

図 2 計算を行った観測点と中京地域の堆積盆地を主に構成する層

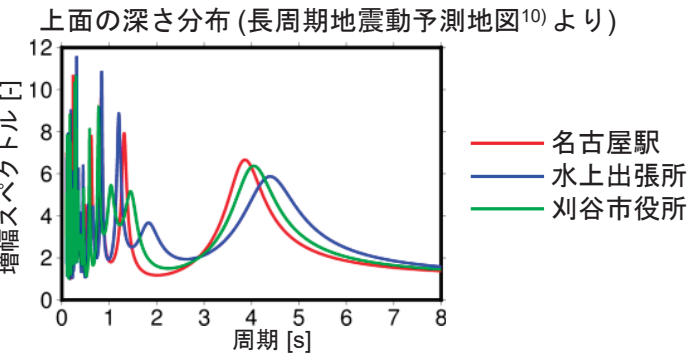

図 3 各観測点における増幅スペクトル

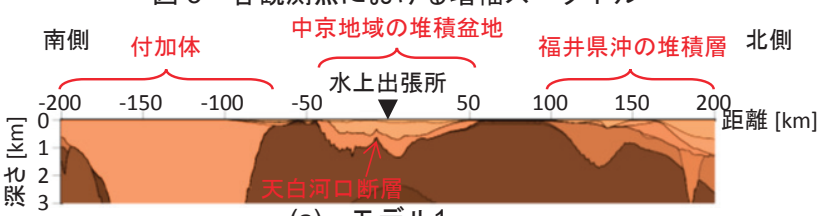

(a) モデル1
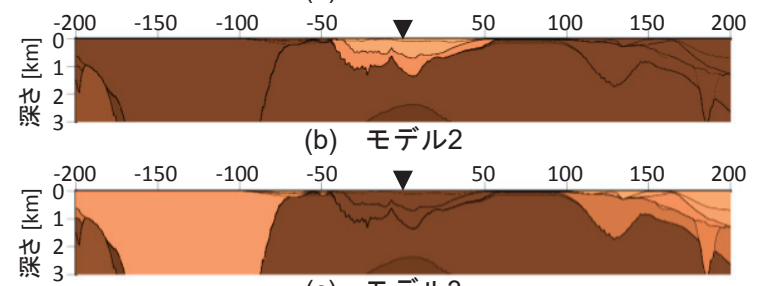

(c) モデル3

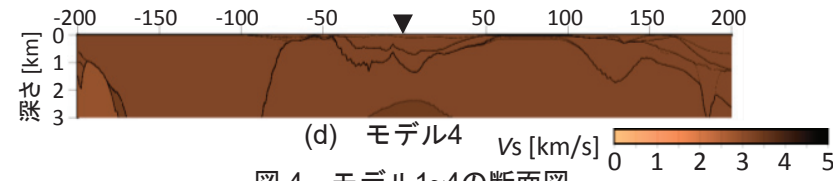

図 4 モデル1 4の断面図

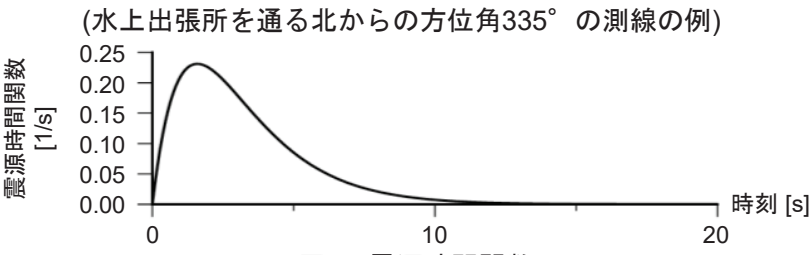

図5 震源時間関数

考えられる. 刈谷市役所では, 周期 $3 \sim 5 \mathrm{~s}$ において北側の地震動が大 きく (図 7 (c) 中の黒色破線で囲んだ領域), 周期 3 5 $\mathrm{s}$ で他の観測 点よりも付加体付近の震源における振幅が大きい (図 7 (c) 中の白 色破線で囲んだ領域).

ところで, 付加体のある位置から伊豆半島の付け根にかけて応答 スペクトルの值が大きくなる領域が帯状に現れている (図 7 (a) の 周期 5 6 s の図中で白色破線で囲んだ領域，他の図でも見られる)． この位置の深さ $10 \mathrm{~km}$ の地点にはフィリピン海プレート上面に位置 する低速度層 (表 2 の第 18 層, 海洋性地款第 2 層 $V_{\mathrm{S}}=2.9 \mathrm{~km} / \mathrm{s}$ 層) 

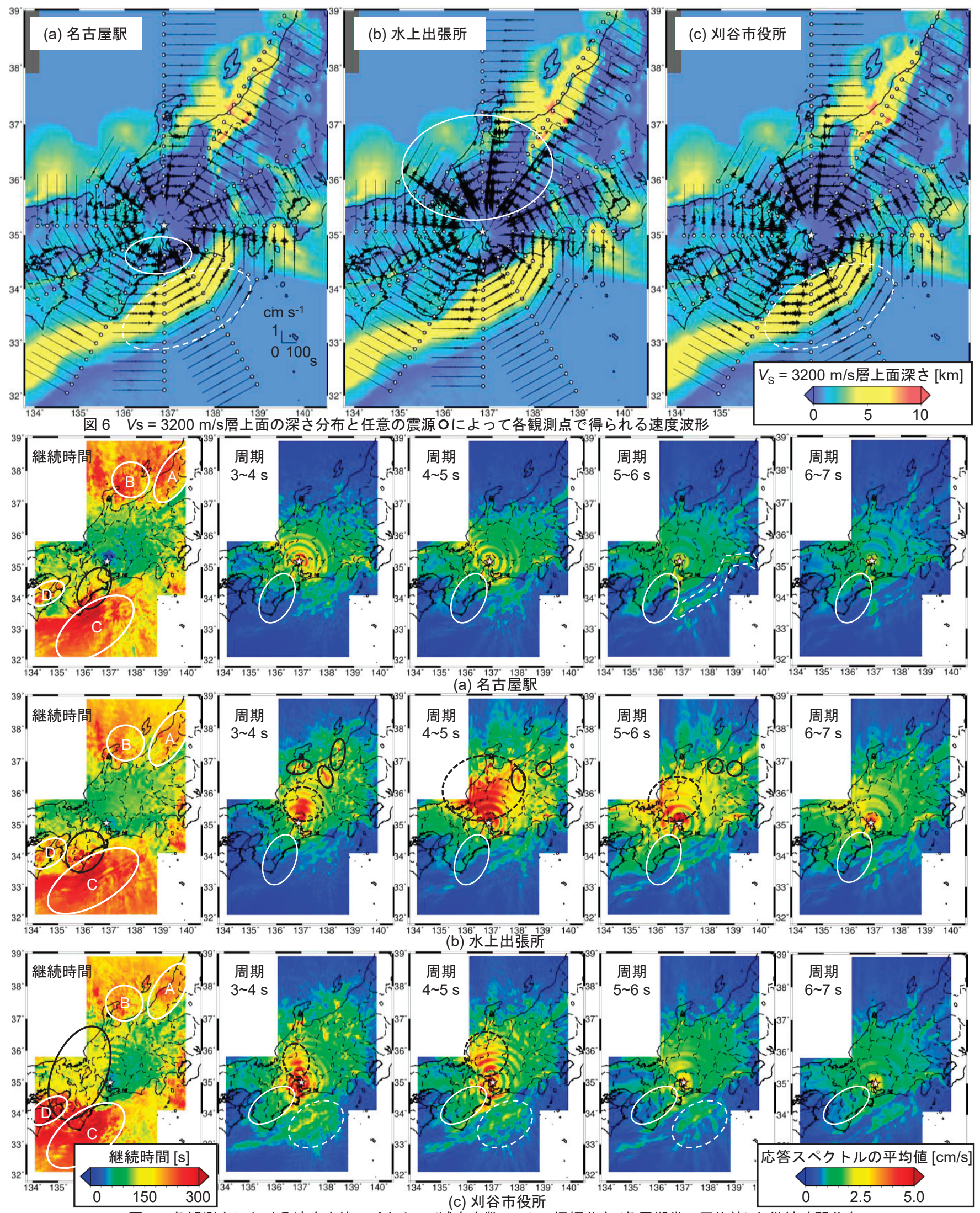

図 7 各観測点における速度応答スペクトル (減衰定数0.01) の振幅分布 (各周期帯の平均値) と継続時間分布

が存在している．この低速度層に震源を設置した場合，大きな振幅と考えられる。

が現れることが知られており ${ }^{17), 18)}$, 図 7 の結果は整合的である.

なお，図 7 では観測点近傍で同心円状の卓越が見られるが，これ

は $\mathrm{P}$ 波と $\mathrm{S}$ 波の走時差による見かけの卓越周期に影響を受けたもの

2.2.4 周期特性と PGV

図 8 (a) 〜 (c) に, モデル 1 による計算結果の震央距離に対する 


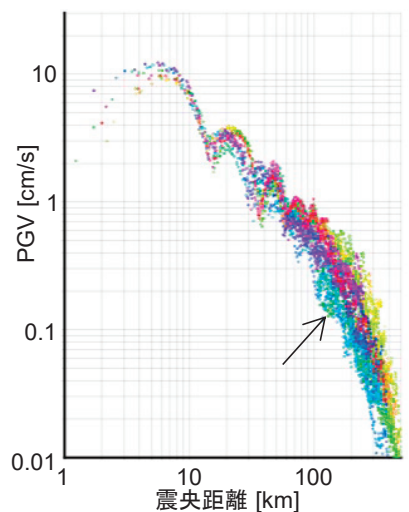

(a) 名古屋駅

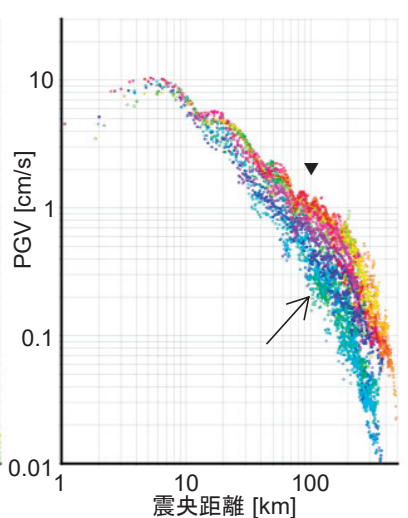

(b) 水上出張所

図 8 各観測点のPGV
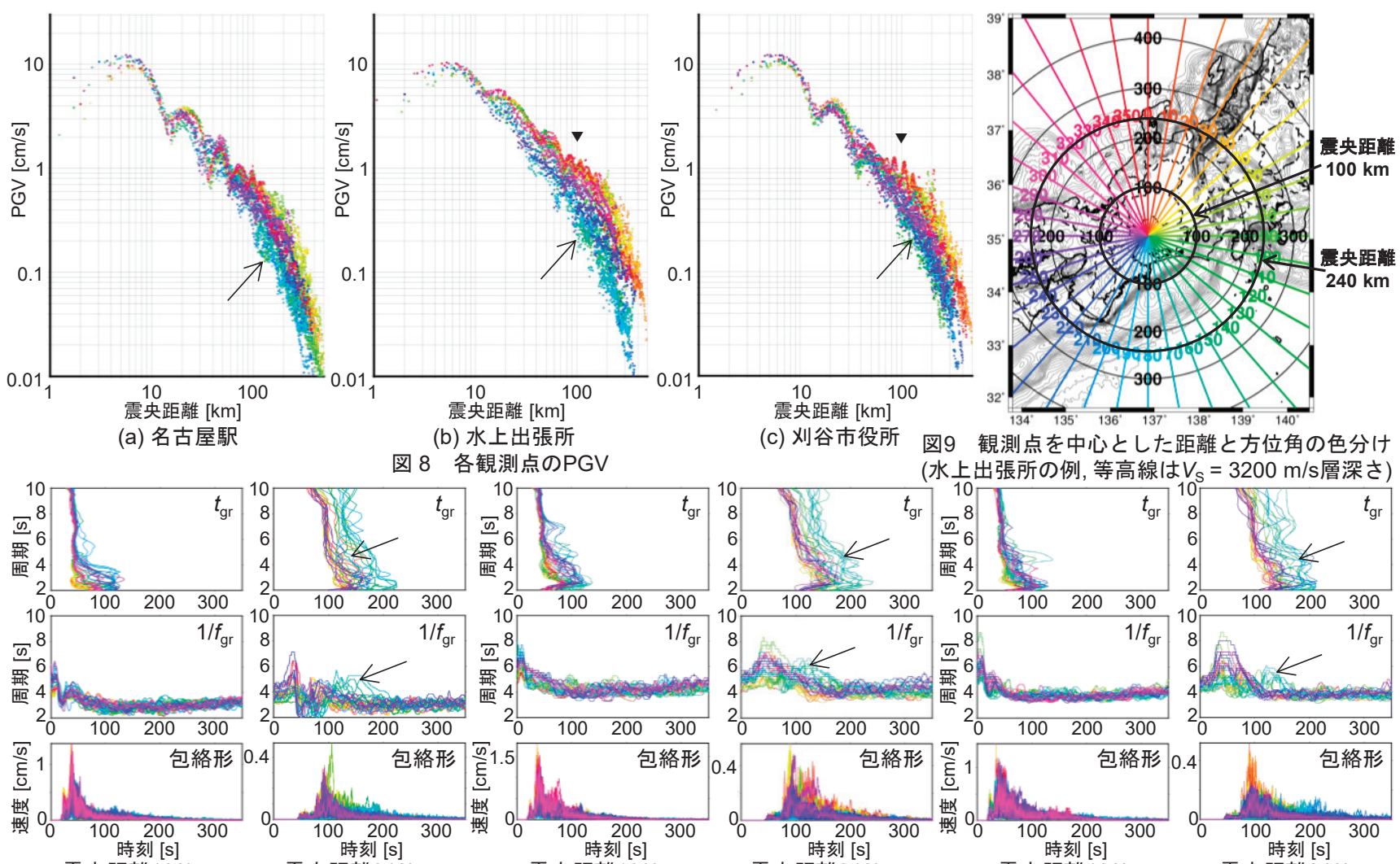

(c) 刈谷市役所

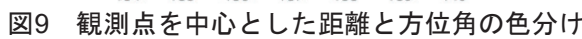
(水上出張所の例, 等高線は $V_{\mathrm{s}}=3200 \mathrm{~m} / \mathrm{s}$ 層深さ)
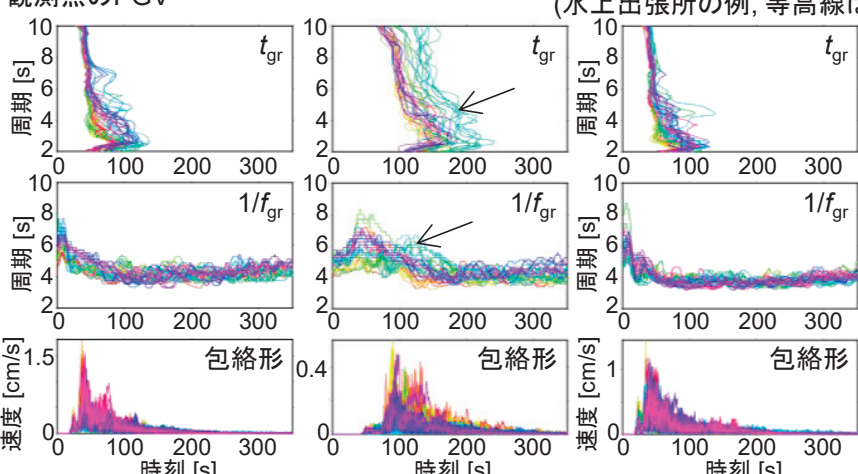

震央距離 $100 \mathrm{~km}$

(b) 水上出張所

(a) 名古屋駅

図 10 各観測点の $t_{\mathrm{gr}}, f_{\mathrm{gr}}$, 包絡形
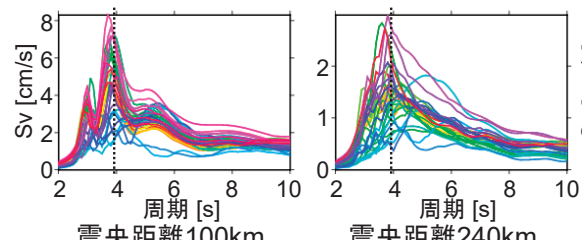

(a) 名古屋駅

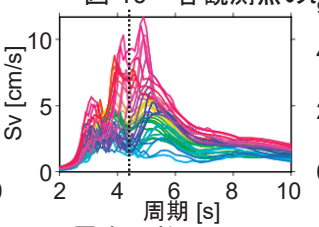

震央距離 $100 \mathrm{~km}$

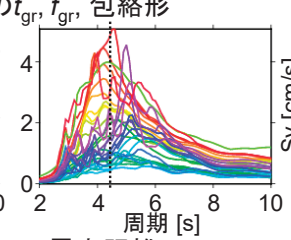

(b) 水上出張所

図 11 各観測点の速度応答スペクトル (減衰定数 0.01 , 各スペクトルの最大值で基準化)

震央距離 $100 \mathrm{~km}$

(c) 刈谷市役所

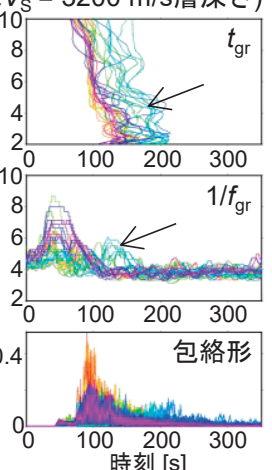

央距離 $240 \mathrm{~km}$

(黒色点線 : 図3の増幅スペクトルから読み取った各観測点の一次卓越周期)

PGV (地表最大速度振幅) の分布を示す。また，図 9 に観測点を中 心とした距離と, $10^{\circ}$ 刻みで色分けした方位角について示寸. PGV の分布では, 名古屋駅と水上出張所で震央距離約 $50 \mathrm{~km}$ 以上で南側 (淡青色, 図 8 中に矢印で示す) の值が小さくなっている. 付加体を 越えない震央距離 (約 $100 \mathrm{~km}$ 以下) でも南側の值が小さいため, 中 京地域の堆積盆地構造が名古屋駅と水上出張所における南側の地震 のPGV を小さくするのに寄与していると考えられる.これは図 7 の 速度応答スペクトル分布と整合寸る. 加えて, 水上出張所と刈谷市 役所においては震央距離約 $50 \mathrm{~km}$ 以上で北側 (赤色, 図 8 中に三角 印で示す) の值が大きくなっている.これは, 図 7 において水上出 張所は 3 6 s, 刈谷市役所は $3 \sim 5 \mathrm{~s}$ において北側の地震の応答スペク トルの值が顕著に大きいことと整合する.

図 10 に, モデル 1 による計算結果の各観測点で得られた震央距離 $100 \mathrm{~km}$ と $240 \mathrm{~km}$ の震源による地震動の $t_{\mathrm{gr}}$ (群遅延時間) $・ f_{\mathrm{gr}}$ (瞬時 振動数) ${ }^{19)}$ ・速度波形の包絡形を示す.なお, 震央距離 $100 \mathrm{~km}$ では 震源は付加体の手前にあり, $240 \mathrm{~km}$ では震源は付加体より南側にあ たる. 図 10 から,$t_{\mathrm{gr}} \cdot f_{\mathrm{gr}}$ の分布は 3 観測点とも共通しているのが分 かる. 震央距離 $100 \mathrm{~km}$ では $t_{\mathrm{gr}} \cdot f_{\mathrm{gr}} \cdot$ 包絡形ともに方位による変動が 少ないが, 距離 $240 \mathrm{~km}$ では $t_{\mathrm{gr}} \cdot f_{\mathrm{gr}}$ ・包絡形ともに変動している. 特
に震央距離 $240 \mathrm{~km}$ では, 地震波が付加体を通過する方向 (淡青色, 図 10 中に矢印で示す) の $t_{\mathrm{gr}}$ の遅れが顕著であり, $f_{\mathrm{gr}}$ は時刻 100 200 s において長周期側になり, 周期 4 6 s が卓越している (図 10 中に矢 印で示す)。これより, 付加体は中京地域の観測点に対し, 地震動の 継続時間を伸ばし, 周期 4 6 s のエネルギーをよく通過させると考 えられる。

図 11 に, モデル 2 による各観測点での震央距離 $100 \mathrm{~km}$ と $240 \mathrm{~km}$ の震源による地震動の速度応答スペクトルを示す.モデル 2 では, 伝播経路を岩盤と同じ物性值としたため, 震源位置依存サイト・堆 積盆地干渉効果を抽出することができる. 図 3 の増幅スペクトルか ら得られる卓越周期 (黒色点線) と比べ, 周期が変動すると共に幅 広い周期で卓越が認められる. 特に水上出張所のピークは, 南側に 震源が位置している場合に長周期化し, 振幅が小さくなっているこ とが分かる (青色)．これは中京地域の堆積盆地内を通過する距離 の違いで, $\mathrm{P}$ 波と $\mathrm{S}$ 波の走時差が異なることに起因する可能性がある. また, 震央距離によるピーク周期の変動は, $\mathrm{P}$ 波と $\mathrm{S}$ 波の走時差また は $V_{\mathrm{S}}=3200 \mathrm{~m} / \mathrm{s}$ 層以深の地下構造の影響によると考えられる. 

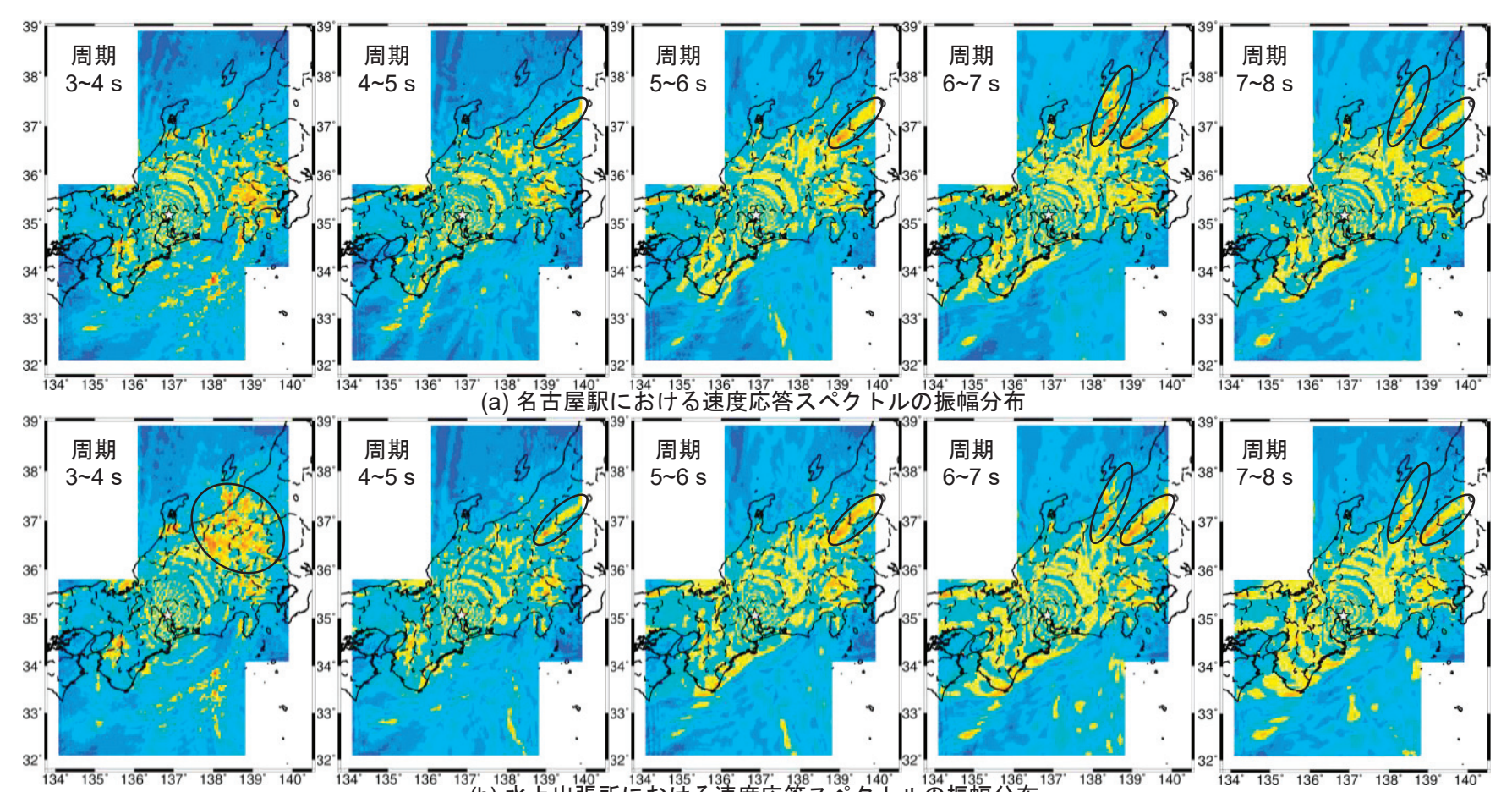

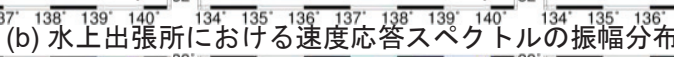
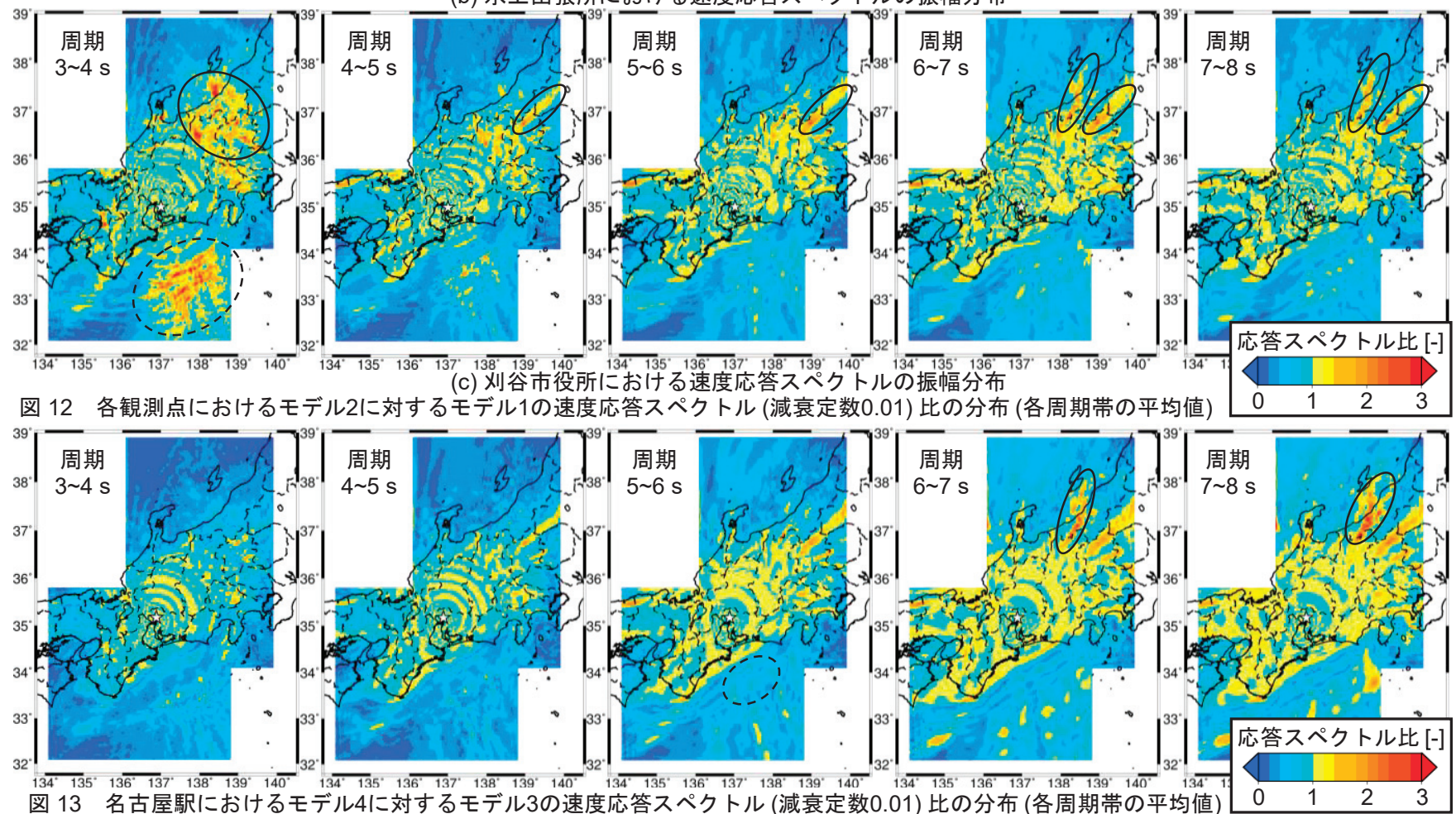

\section{2 .5 伝播経路特性の影響の抽出}

モデル 1 の結果には, 伝播経路特性と震源位置依存サイト・堆積 盆地干渉効果の両方が影響している.これら 2 つの影響を見分ける ため，伝播経路特性の影響を抽出する. 図 12 に，モデル 2 に対する モデル 1 の計算結果の, 各周期帯における応答スペクトル比の分布 を示す。この図では, 伝播経路特性による影響に加え, 後述する伝 播経路と震源位置依存サイト・堆積盆地干涉による相乗効果が含ま れていると考えられる. 図 12 から, 3 観測点とも周期 3 4 $\mathrm{s}$ において, 応答スペクトルの值が大きいところが多く見られる.これらは伝播 経路特性である付加体や陸上の堆積層があることによると考えられ
る.この分布は 3 観測点で異なっており, 伝播経路と震源位置依存 サイト・堆積盆地干渉による相乗効果によると考えられる. 既往の 研究と同椂に，付加体の存在を考慮すれば地震波が付加体を越えて くる震源位置で振幅が小さくなっているが，刚谷市役所においては 振幅が大きくなっている (図 12 (c) 中の黒色破線で囲んだ領域) モデル 1 では, 地震波伝播経路上に付加体が存在するため, 中京地 域の堆積盆地には主に表面波が南から入射する. 図 2 の $V_{\mathrm{S}}=600$ $\mathrm{m} / \mathrm{s}$ 層上面深さ分布より, 刈谷市役所は南北に細長く分布する軟弱 地盤の北の端に位置している. 刈谷市役所では, この谷状地形によ り表面波が増幅した可能性がある。また, 各観測点において長野県 
北部から新潟にかけてと群馬県北部に, 值が大きくなる領域が見ら

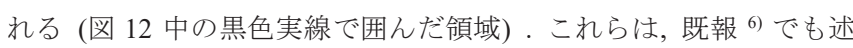
べたように, 新潟堆積盆地内の地震基盤が局所的に深いところや, 群馬県西の堆積盆地により, 地震動のある周期帯の振幅が増幅され たと考えられる.

次に, 名古屋駅について, モデル 4 に対するモデル 3 の計算結果 の各周期帯における応答スペクトルの比を図 13 に示す.この図で は中京地域の堆積盆地を岩盤としたモデル同士で比をとっているた め, 伝播経路と震源位置依存サイト・堆積盆地干渉による相乗効果 は含まれていない. 図 13 より, 付加体を通過する周期 5 6 s の地震 波の振幅はあまり小さくなっていない (図 13 中の黒色破線で囲ん だ領域) が，そのほかの周期帯では地震波の振幅が小さくなってい る.また，新潟堆積盆地に着目すれば，周期 6 8 s において，地震波 の振幅が大きくなるように作用している (図 13 中の黒色実線で囲 んだ領域).

\section{3. 北側の地震による波動伝播}

2 章では, 震源位置依存サイト・堆積盆地干渉効果により, 水上出 張所において, 北側の地震で他と比較して顕著に振幅が大きく, 振 幅が大きい時間が長く続くという結果が得られた。この現象の原因 を調べるため, 本章では北側の震源について, 地震波伝播の様子を 考察した. 図 14 に, 計算領域と震源位置を示寸. 震源の位置は水上 出張所の北方 $60 \mathrm{~km}$ とし, 深さ $10 \mathrm{~km}$, 震源パラメータは 2 章の検討 と同様に設定した.

図 15 に, 地震波伝播のスナップショットを示寸 (速度の南北成 分). 図 15 (a), (b) から, 北から堆積盆地に入射した地震波は, 水上 出張所の東側で反射し，水上出張所において振幅が大きくなってい るように見える (図 15 (a), (b) 中の矢印で示した場所)。さらに, 図 15 (c) から, 水上出張所の北東の領域で, 地震波が滞留しているよ うに見える (図 15 (c) 中の黒色破線で囲んだ領域). 水上出張所の 南東には天白河口断層が位置し, 図 14 に見える通り, $V_{\mathrm{s}}=1300 \mathrm{~m} / \mathrm{s}$ 層の深さが急激に変わっている.この天白河口断層による層の段差 と水上出張所の位置関係は, 図 4 (a) の断面図に示寸通りである. 天 白河口断層による地層構造の段差により，地震波が滞留していると 考えられる.このような地層の段差に地震波が反射され，振幅が大 きくなる現象は吉村 ${ }^{20)}$ も指摘している.

\section{4. 単純 2 層モデルによる検討}

3 章では, 天白河口断層による層の段差が, 北側で地震が起きた 際の水上出張所における振幅が大きな地震動と, その継続時間に影 響を与える可能性が示唆された。本章では, 層の段差が地震波に与 える影響について, 単純 2 層モデルを用いた検討を行う. 図 16 に計 算に使用した地盤構造モデルの平面図と断面図, 堆積盆地断面のイ メージ図を, 表 3 に各層の物性值を示寸. 格子形状は, 地表から深 さ $4 \mathrm{~km}$ までは一辺 $200 \mathrm{~m}$, それ以深は一辺 $600 \mathrm{~m}$ の立方体形であり, 解析の有効周期は $1 \mathrm{~s}$ 以上である. 地盤モデルは, 平面は直径 $50 \mathrm{~km}$ の円形，断面は基盤が南側に傾斜した形状となっており，南側の基 盤段差を, 水上出張所近傍の天白河口断層による層の段差に見立て ている. 南側の基盤段差の近傍に観測点を配置し, 深さ $10 \mathrm{~km}$ の任 意の位置で地震が起きた際に観測点で得られる地震動を計算した。
図 17 に任意の震源によるラディアル方向の速度波形を, 図 18 に, 震央距離 $50 \mathrm{~km}$ の震源位置 $\mathrm{A}, \mathrm{B}$ での地震による観測点でのラディア ル方向の速度波形及び速度応答スペクトルを示す，振幅及び継続時 間のスケールは統一してあり, 距離減衰補正は行っていない. 図 17 より，観測点から見て堆積盆地の背面の北側の震源による地震動の 振幅が大きく, 継続時間が長い. 図 18 で震源位置 $\mathrm{A}$ と B による波形 を比較すれば，前者は主要動にパルスが一つあるのみで，地震波が 観測点付近に留まっていないことが分かる，一方，後者は，振幅の 大きい主要動が長く続いている. 堆積盆地内での表面波の分散現象 に加え，観測点近傍の岩盤の段差で地震波が反射・干涉し，観測点 での地震動を増幅・伸長させたものと推察される。応答スペクトル においても，全周期帯で震源位置 $\mathrm{B}$ による振幅が A による振幅を上 回っていることが分かる.

以上より, 2.2 節でみられた水上出張所の北側の地震による地震動 の大きな振幅と長い継続時間は, 天白河口断層による地震波の反 射・干渉によると考えられる

\section{5. 地震動観測記録による検討}

\section{1 検討手法と使用した地震 ・ 観測点}

地震動観測記録から, 中京地域における震源位置依存サイト・堆 積盆地干渉効果を, 岩盤観測点との擬似速度応答スペクトル (減衰 定数 0.01) 比より抽出し, 震源域ごとに比較を行った.

検討対象とした地震 ${ }^{21)}$ を表 4 に, 震源と岩盤観測点の位置を図 19 に示す. マグニチュード 5.0 以上かつ震源深さ $0 \sim 20 \mathrm{~km}$ で, 中京地域 において多く地震動記録が得られている地震を対象とした。検討に 使用した強震観測点は，防災科学技術研究所の K-NET, KiK-net ${ }^{22)}$ と, 大都市圈強震動総合観測ネットワークシステム ${ }^{23)}$ に含まれる愛知 県, 三重県及び名古屋市が設置した強震観測点, 中部電力が設置し た強震観測点，全 310 点である。

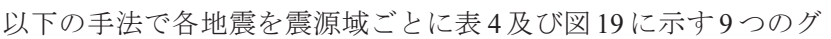
ループに分け, グループごとに各観測点における応答スペクトル比 を平均した。 まず, 中京地域の全観測点における擬似速度応答スペ クトル (減衰定数 0.01) を算出し, 震央距離の平方根を乗じて基準 化した. 次に, 中京地域の堆積盆地の中心からの距離が $80 \mathrm{~km}$ 以下 の岩盤観測点を, 図 19 に示寸とおり東西南北の 4 つのグループに分 類した. 岩盤観測点は, 長周期地震動予測地図 ${ }^{10)}$ の地盤モデルを用 いて $V_{\mathrm{S}}=3200 \mathrm{~m} / \mathrm{s}$ 層から地表までの増幅スペクトルを計算し，周期 $1 \mathrm{~s}$ 以上における值が 1.5 以下である観測点とした。ささらに, 各地震 について, 表 4 に示寸岩盤観測点グループで得られた距離減衰補正 処理後の擬似速度応答スペクトルを平均した，次に，地震ごとに全 観測点の応答スペクトルを, 震源方向の岩盤観測点グループの応答 スペクトルの平均で割り, 応答スペクトル比を算出した. 最後に, 震源域ごとに各観測点における応答スペクトル比を平均した.

震源域ごとにグループを分ける際，原則として同一の伝播経路特 性の影響を受けると思われる地震を同じグループとした，特に，震 源位置が近くても新潟堆積盆地の影響を受ける新潟付近の 4 地震と, 地震波が新潟堆積盆地を通過しない神城断層地震は別とした。ただ し, 紀伊半島南東沖の 4 地震と三重県南東沖の地震は震源位置が近 くても応答スペクトル比の分布が顕著に異なった特徵を示すため別 とした. また, 淡路島の地震と熊本の地震は, 震源位置は離れてい 

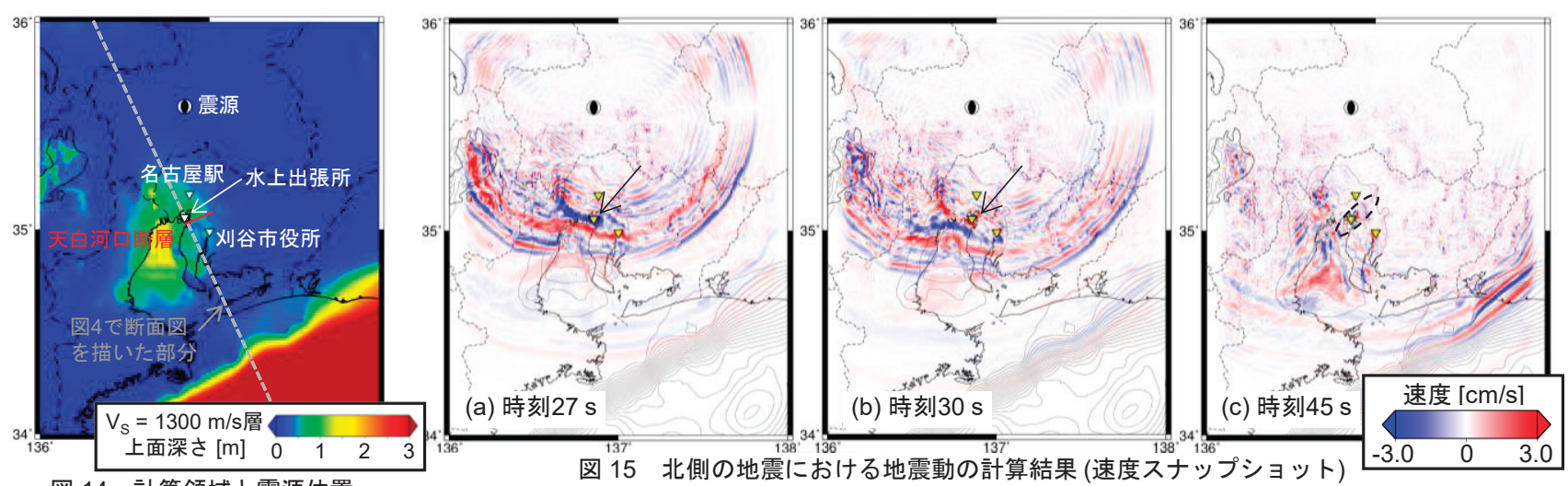

図 14 計算領域と震源位置
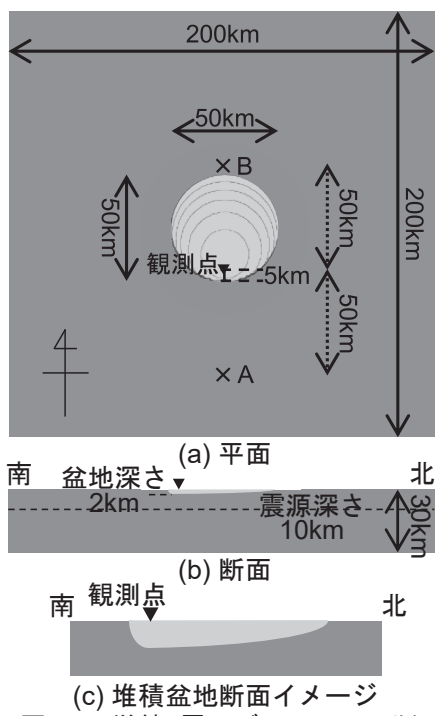

北

6 単純2層モデルの平面・断面

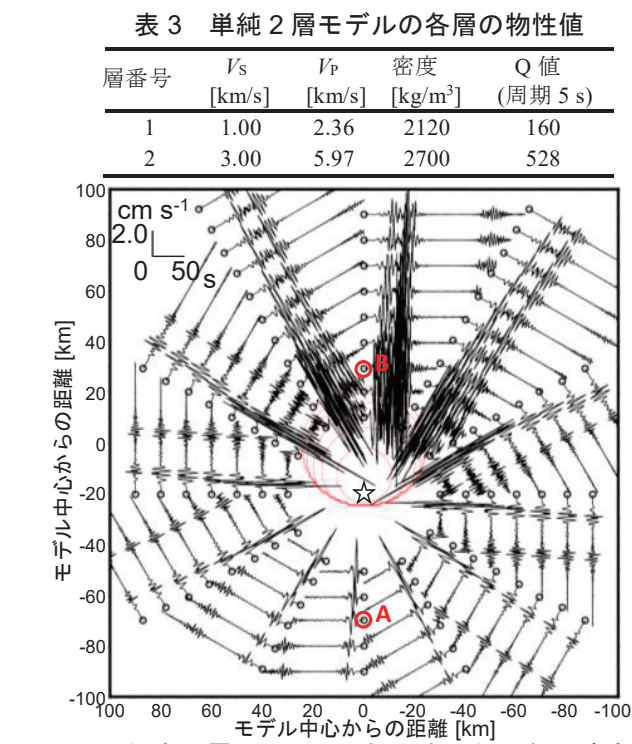

図 15 北側の地震における地震動の計算結果 (速度スナップショット)

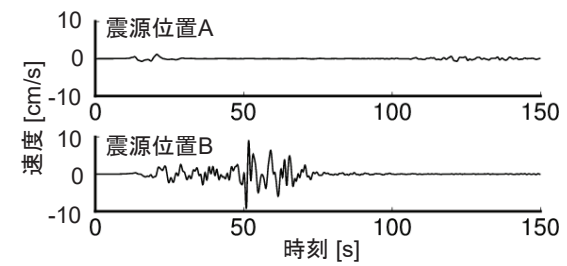

(a) 速度波形

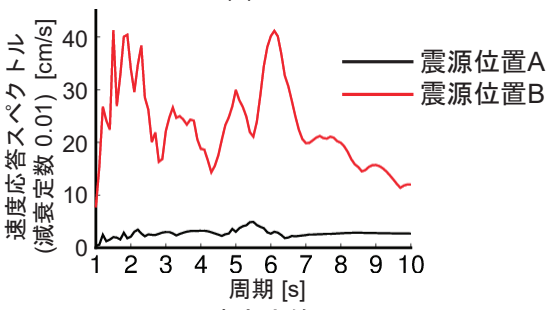

(b) 速度応答スペクトル

図 18 観測点で得られる速度波形と 速度応答スペクトル (減衰定数 0.01)

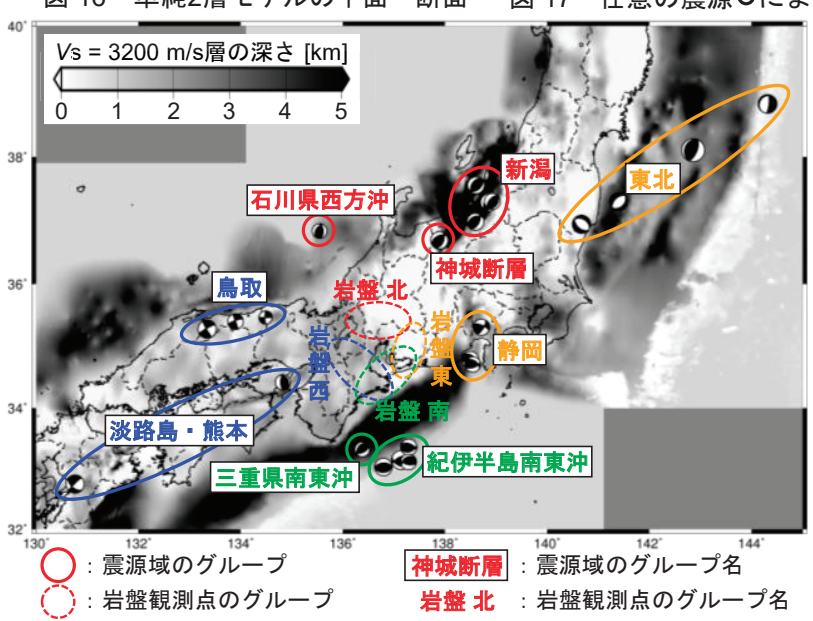

図 19 検討対象とした地震の震源・岩盤観測点位置・グループ分け

るが中京地域の堆積盆地への地震波の入射方位が同一で, 応答スペ

クトル比の分布が似た特徴を示すため 1 つのグループとした.

\section{2 各周期帯における擬似速度応答スペクトルの平均値分布}

図 20 に各震源域のグループごとのラディアル方向の擬似速度応 答スペクトル比 (固有周期幅 $1 \mathrm{~s}$ の区間の平均值) を示寸. 周期 $2 \sim 6 \mathrm{~s}$ で静岡, 周期 4 $6 \mathrm{~s}$ では東北の地震において, 愛知県西端で大きく増 幅していることが分かる.4 章の検討結果と同様に, 観測点と養老断 層, 静岡 - 東北の震源との位置関係から, 観測点近傍の岩盤の段差 により地震波の反射・干渉が生じ，地震動の増幅・伸長が生じたと

表 4 検討対象とした地震の概要 ${ }^{21)}$

\begin{tabular}{|c|c|c|c|c|}
\hline $\begin{array}{l}\text { 震源域の } \\
\text { グループ名 }\end{array}$ & 日時 & $\begin{array}{c}\text { 震源深さ } \\
{[\mathrm{km}]}\end{array}$ & $M_{\mathrm{W}}$ & $\begin{array}{c}\text { 使用した } \\
\text { 岩盤グループ※ }\end{array}$ \\
\hline 石川県西方沖 & $2000 / 6 / 76: 16$ & 5 & 5.8 & 北 (12) \\
\hline 神城断層 & $2014 / 11 / 22$ 22:08 & 5 & 6.3 & 北 (13) \\
\hline \multirow{4}{*}{ 新潟 (4 地震) } & $2004 / 10 / 2317: 56$ & 5 & 6.6 & 北 (11) \\
\hline & $2004 / 10 / 2318: 34$ & 11 & 6.3 & 北 (9) \\
\hline & $2007 / 7 / 1610: 13$ & 8 & 6.6 & 北 (11) \\
\hline & $2011 / 3 / 123: 59$ & 5 & 6.2 & 北 (13) \\
\hline \multirow{4}{*}{ 東北 (4 地震) } & $2011 / 3 / 11 \quad 14: 46$ & 20 & 8.7 & 東 (33) \\
\hline & $2011 / 4 / 11 \quad 17: 16$ & 5 & 6.6 & 東 (11) \\
\hline & $2012 / 12 / 7 \quad 17: 18$ & 11 & 7.3 & 東 (13) \\
\hline & 2016/11/22 5:59 & 11 & 7.0 & 東 (5) \\
\hline \multirow{3}{*}{ 静岡 (3 地震) } & $2009 / 8 / 115: 07$ & 20 & 6.2 & 東 (14) \\
\hline & $2011 / 3 / 1522: 31$ & 8 & 5.9 & 東 (33) \\
\hline & $2011 / 8 / 123: 58$ & 11 & 5.8 & 東 (32) \\
\hline \multirow{4}{*}{$\begin{array}{c}\text { 紀伊半島南東沖 } \\
\text { (4 地震) }\end{array}$} & $2004 / 9 / 5 \quad 19: 07$ & 14 & 7.2 & 南 (30) \\
\hline & $2004 / 9 / 523: 57$ & 11 & 7.5 & 南 (23) \\
\hline & $2004 / 9 / 78: 29$ & 11 & 6.5 & 南 (27) \\
\hline & $2004 / 9 / 823: 58$ & 5 & 6.1 & 南 (31) \\
\hline 三重県南東沖 & $2016 / 4 / 111: 39$ & 14 & 5.8 & 南 (22) \\
\hline \multirow{2}{*}{$\begin{array}{c}\text { 淡路島・熊本 } \\
\text { (2 地震) }\end{array}$} & $2013 / 4 / 135: 33$ & 11 & 5.8 & 西 (19) \\
\hline & $2016 / 4 / 161: 25$ & 11 & 7.1 & 西 (4) \\
\hline \multirow{3}{*}{ 鳥取 (3 地震) } & $2000 / 10 / 613: 30$ & 11 & 6.6 & 西 (13) \\
\hline & 2001/1/12 8:00 & 8 & 5.2 & 西 (7) \\
\hline & $2016 / 10 / 21 \quad 14: 07$ & 8 & 6.2 & 西 (11) \\
\hline
\end{tabular}

※ 括弧内は岩盤グループ内で記録を使用した観測点数

推察できる。また，全周期帯において，三重県南東沖の地震による 増幅が大きくなっており, 震源が近い紀伊半島南東沖の地震との差 が大きい.これら 2 つの震源では, 震源と観測点の間における付加 体の位置関係が異なっており, 地震波が付加体内を通過する距離が 


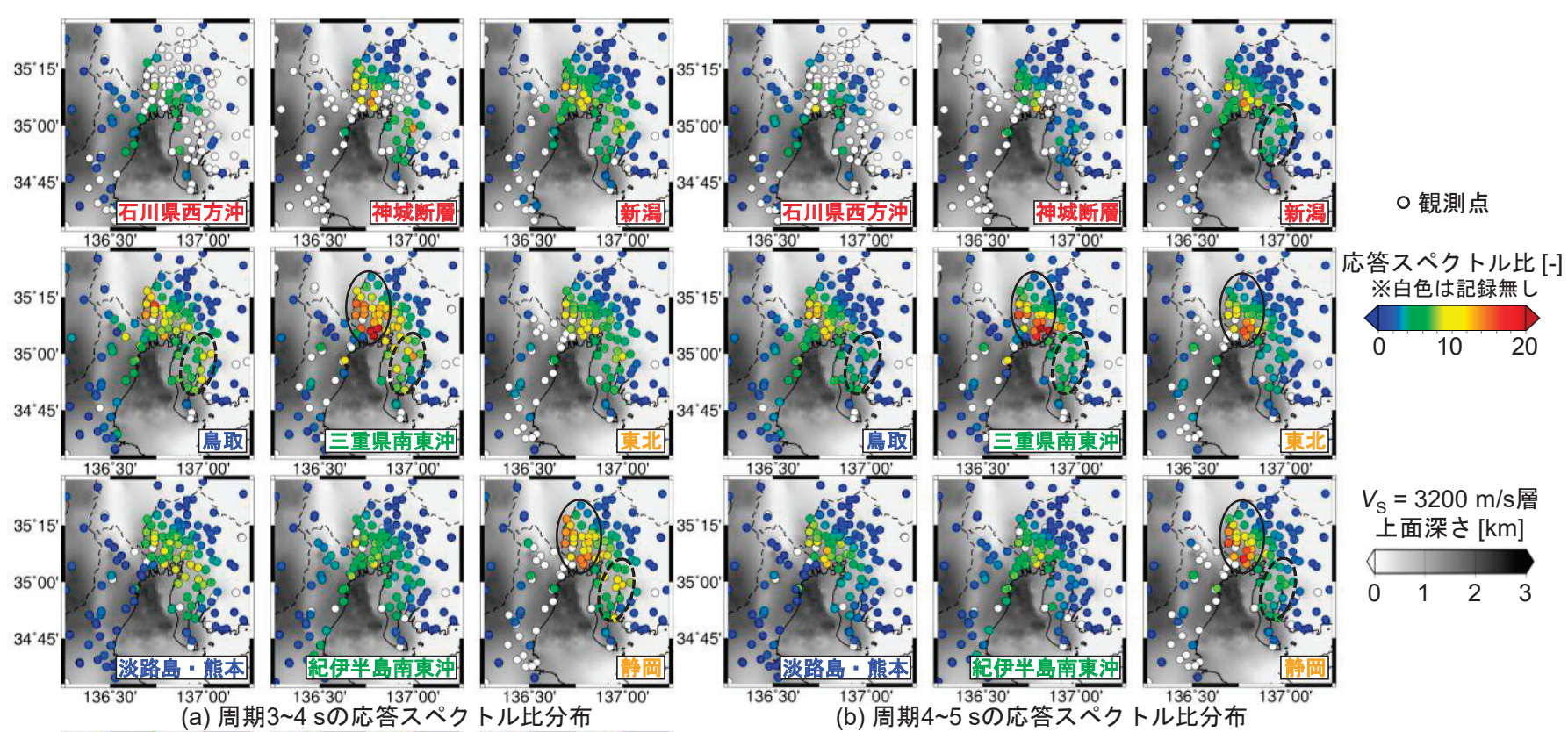

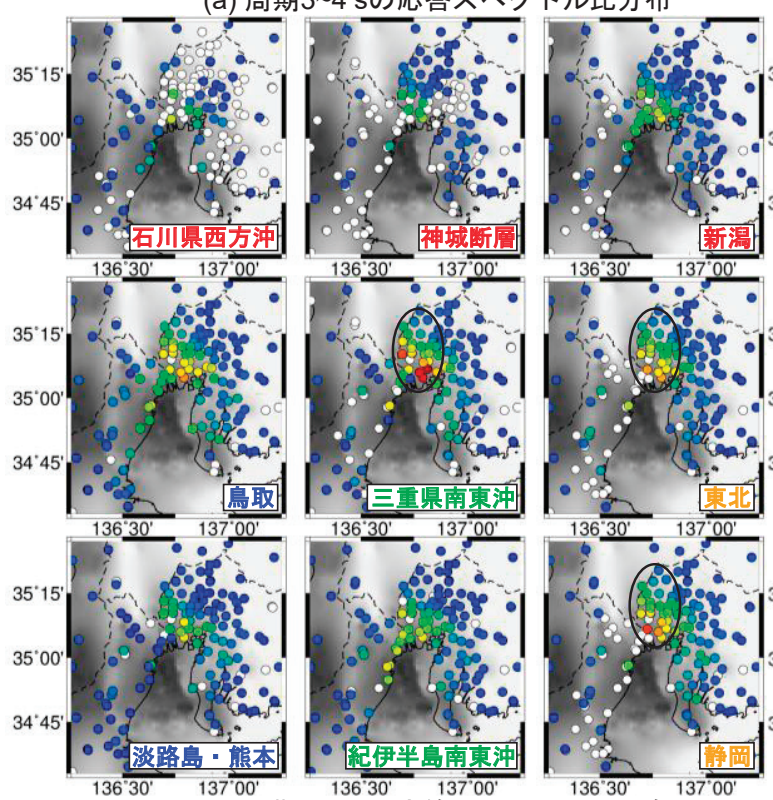

(c) 周期5 6 sの応答スペクトル比分布

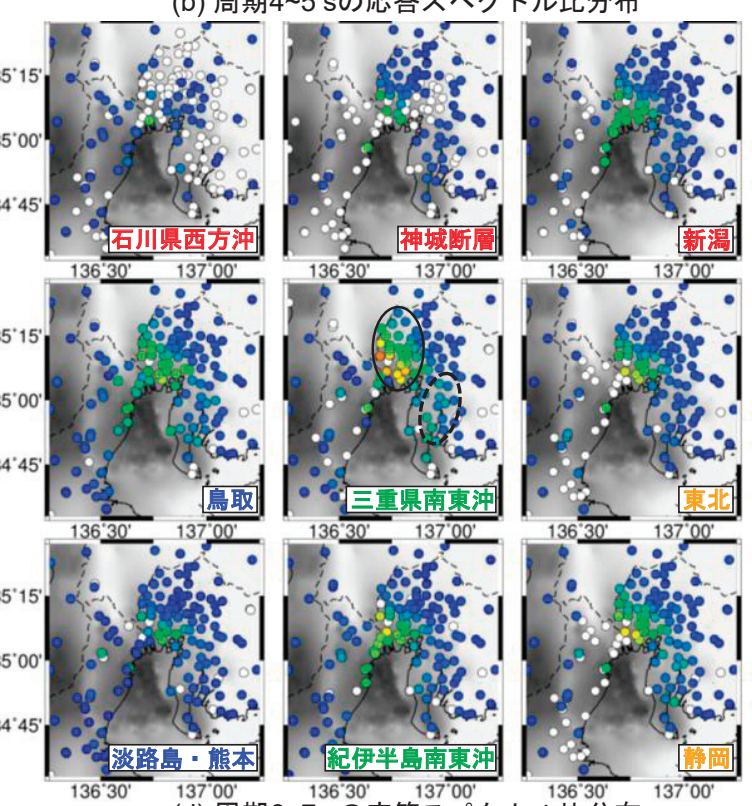

(d) 周期 6 7 7 sの応答スペクトル比分布

$\bigcirc$ 愛知県西端で増幅の大きな領域

図 20 各震源域グループごとの周期別の擬似速度応答スペクトル (減衰定数 0.01) 比の分布 (各周期帯の平均值)

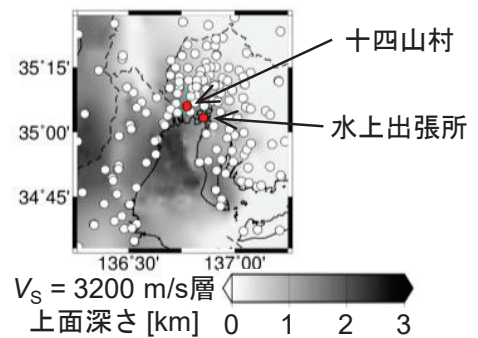

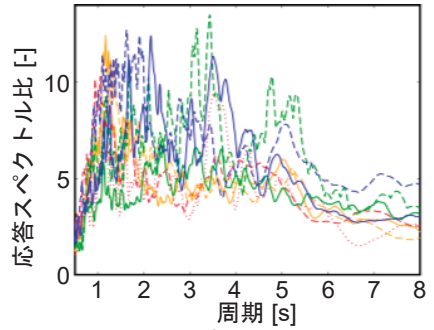

(a) 水上出張所

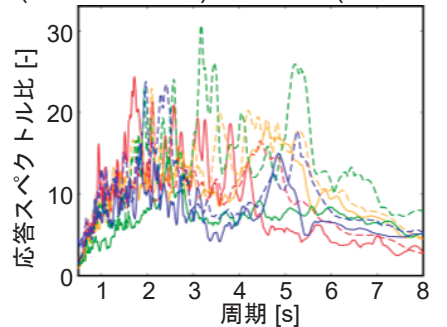

(b) 十四山村

図 21 水上出張所と十四山村における各震源域グループごとの擬似速度応答スペクトル (減衰定数 0.01) 比

異なるため, 付加体がそれぞれの地震の地震波に与える影響は異な ると考えられる.よって, 2.2 .5 項で述べた, 伝播経路と震源位置依 存サイト・堆積盆地干涉による相乗効果が異なることが，これらの 地震の増幅率の違いの原因だと考えられる. また, 新潟の地震と神 城断層地震を比較すれば, 周期 $2 \sim 4 \mathrm{~s}$ では神城断層地震で愛知県西 端における増幅が大きく, 周期 4 7 s では新潟の地震で増幅が大き
くなっている.これも, 伝播経路と震源位置依存サイト・堆積盆地 干渉による相乗効果の違いによると考えられる. さらに, 西三河地 域でも，震源域によって増幅度合いが異なっているのが分かる.

図 21 に, 水上出張所及び愛知県西端に位置寸る十四山村の擬似 速度応答スペクトル比を示す.ただし, 水上出張所における神城断 層地震の記録及び，十四山村における石川県西方沖の地震の記録は 
取れていない. 図より, 両観測点とも震源域ごとに応答スペクトル 比の形状が大きく異なっているのが分かる. 水上出張所は 2 章の解 析結果とは異なり，北側の地震による振幅が特に大きいわけではな い. 水上出張所は天白河口断層に近接しているため, 地形の小さな 差が地震動に与える影響が大きい. 今後, より高解像度の地下構造 モデルを構築し検討を行う必要がある. 一方, 十四山村では, 図 20 で見られた震源域ごとの特徴をよく表しており，観測点によっては 同じ周期帯においても増幅率が 3 4 倍異なることが分かる.

以上より, 中京地域の堆積盆地に対する地震波の入射方向によっ て, 堆積盆地内の地震動の増幅率が異なることが分かった。さらに, 伝播経路の影響が異なれば地震動の増幅傾向が異なり，伝播経路と 震源位置依存サイト・堆積盆地干渉による相乗効果があることが観 測記録からも明らかとなった.ただし, 紀伊半島南東沖の地震と比 較して三重県南東沖の地震の増幅率が大きい原因は詳細には分かっ ておらず, 今後の課題である.

\section{6. まとめ}

本論文では，相反定理を用いた有限差分法による解析から，伝播 経路特性と震源位置依存サイト・堆積盆地干渉効果が, 中京地域一 伝播する地震波に与える影響を示した。 また, 中京地域の堆積盆地 が地震動に与える影響について, 地震波伝播の様子による考察と単 純モデルを用いた検討を行い, 堆積盆地一の地震波の入射方位の違 いによる地盤震動特性の変動が観測点近傍の不整形な地盤構造に起 因することを確認した，さらに，地震動観測記録を用いて岩盤観測 点との応答スペクトル比を算出することにより, 中京地域の堆積盆 地上の地点における地震動の増幅率が震源域に依存し, 単純モデル を用いた解析で得られた結果と同様の傾向を示していることを明ら かにした. 特に, 名古屋市を含む愛知県西部と自動車産業が集積し ている西三河地域では, 地震の震源域によって震源位置依存サイ ト・堆積盆地干渉効果による増幅の度合いが異なることが分かった。 震源位置の違いで地震動が大きく異なることから, 経験的グリー ン関数法に使用する地震動観測記録の取扱いには注意が必要となる. また, 震源の位置によっては特定の長周期構造物の応答が大きくな る可能性があり，伝播経路特性及び震源位置依存サイト・堆積盆地 干渉効果が地震動に与える影響を評価することは有用であると考え られる. 特に, 高層建物が集中する地域については, 2 章で行ったよ うな相反定理を用いた検討を事前に行っておくことは有効である.

\section{謝辞}

防災科学技術研究所 ${ }^{22)}$ の K-NET および KiK-net による地震動観 測記録, 大都市圏総合強震観測ネットワークシステム ${ }^{23)}$ に統合さ れている愛知県と三重県, 名古屋市の地震動観測記録, 及び中部電 力の地震動観測記録を使用した．地震の震源情報として，防災科学 技術研究所 ${ }^{21)}$ の F-net によるメカニズム解を使用した. また，図の 作成に Generic Mapping Tools ${ }^{24)}$ を使用した.

\section{参考文献}

1) 文部科学省 研究開発局, 国立大学法人 東京大学大学院情報学環: 東 海・東南海・南海地震の連動性評価研究プロジェクト (2) 連動性を考慮 した強震動・津波予測及び地震・津波被害予測研究 平成 22 年度 成果報 告書, pp. 7-37, 2011.5
2) 渡辺哲史, 永野正行, 加藤研一：南海トラフ沿いの付加体および震源位 置が東京の長周期地震動に及ぼす影響, 日本建築学会構造系論文集, 第 79 巻, 第 700 号, pp. 701-710, 2014. 6

3) 渡辺哲史, 加藤研一, 永野正行: 南海トラフ沿いの付加体が中京地区の 長周期地震動に及ぼす影響, 日本建築学会大会学術講演梗概集, 構造 II, pp. 257-258, 2014. 9

4) 山田沙代, 平井敬, 福和伸夫：地震動観測記録と有限差分解析に基づく 中京地域で観測される長周期地震動の震源位置依存性に関する研究, 日 本建築学会構造系論文集, 第 81 巻, 第 728 号,pp. 1647-1656, 2016. 10

5) 寺島芳洋, 高橋広人, 福和伸夫, 護雅史: 堆積盆地における地盤と超高層 建物との共振現象に関する研究 その 1 大阪平野の地盤周期の分析と強 震動予測, 日本建築学会大会学術講演梗概集, B-2, pp. 151-152, 2012.9

6) 津野靖士, 山中浩明, 翠川三郎, 山本俊六, 三浦弘之, 酒井慎一, 平田直, 笠原敬司, 木村尚紀, 明田川保: 2011 年東北地方太平洋沖地震 ( $\left.\mathrm{M}_{\mathrm{W}} 9.0\right)$ の本震記録と余震記録を用いた首都圈およびその周辺地域に於ける長周 期地震動の特性, 日本地震工学会論文集, 第 12 巻, 第 5 号 (特集号), 2012. 11

7) 平井敬, 福和伸夫: 3 次元有限差分法と相反定理を用いた堆積盆地の地盤 震動性状の評価手法, 日本建築学会構造系論文集, 第 78 巻, 第 694 号, pp. 2083-2091, 2013. 12

8) 山田沙代, 平井敬, 福和伸夫：地震動観測記録の表面波部の震源位置依 存性, 日本建築学会大会学術講演梗概集, 構造 II, pp. 49-50, 2015.9

9) Furumura, T. and Hayakawa, T. : Anomalous propagation of long-period ground motions observed in Tokyo during the 23 October 2004 Niigata-ken Chuetsu ( $\mathrm{M}_{\mathrm{W}}$ 6.6) earthquake, Bulletin of the Seismological Society of America, Vol. 97, No. 3, pp. 863-880, 2007. 6

10) 地震調查研究推進本部 地震調査委員会: 「長周期地震動予測地図」 2012 年度試作版 - 南海地震 (昭和型) の検討一, http://www.jishin.go.jp/ main/chousa/12_chosyuki/index.html (2016. 10. 26 閲覧), 2012. 1

11) Graves, R. W. : Simulating seismic wave propagation in $3 D$ elastic media using staggered-grid finite differences, Bulletin of the Seismological Society of America, Vol. 86, No. 4, pp. 1091-1106, 1996. 8

12) Levander, A.R. : Fourth-order finite difference P-SV seismograms, Geophysics, Vol. 53, pp. 1425-1436, 1988. 11

13) Aoi, S. and Fujiwara, H. : 3D finite-difference method using discontinuous grids, Bulletin of the Seismological Society of America, Vol. 89, No. 4, pp. 918-930, 1999. 8

14) Clayton, R. and Engquist, Björn : Absorbing boundary conditions for acoustic and elastic wave equations, Bulletin of the Seismological Society of America, Vol. 67, No. 6, pp. 1529-1540, 1977. 12

15) Cerjan, C. , Kosloff, D. , Kosloff, R. and Reshef, M. : A non-reflecting boundary condition for discrete acoustic and elastic wave-equations, Geophysics, Vol. 50, pp. 705-708, 1985. 4

16) Boore D. M. : Stochastic simulation of high-frequency ground motions based on seismological models of the radiated spectra, Bulletin of the Seismological Society of America, Vol. 73, No. 6, pp. 1865-1894, 1983. 12

17) 田中清和, 野畑有秀: 南海トラフ巨大地震による長周期地震動評価 (そ の 2) 連動地震の試算と震源深さと地款構造の関係による影響の検討, 日本建築学会大会学術講演梗概集, 構造 II, pp. 259-260, 2014.9

18) 後藤賢人, 永野正行: フィリピン海プレート境界上面の低速度層が大阪 平野内の長周期地震動に与える影響, 日本建築学会大会学術講演梗概集, 構造 II , pp. 29-30, 2015.9

19) Papoulis, A. : The fourier integral and its applications, McGraw-Hill Book Company, pp. 134-136, 184-187, 1962

20) 吉村智昭: 濃尾平野における想定東南海地震の長周期地震動評価一領 域縮小法による地震波動伝播解析一, 大成建設技術センター報, 第 37 号, 2004

21) 防災科学技術研究所: http://www.fnet.bosai.go.jp/ (2016.10.26 閲覧)

22) 防災科学技術研究所: http://www.kyoshin.bosai.go.jp/kyoshin/ (2016. 10. 26 閲覧)

23) 大都市圏強震動総合観測ネットワークシステム（東海地域）： http://ansei.seis.nagoya-u.ac.jp/（2016.10.26 閲覧）

24) Wessel, P. , Smith, W. H. F., Scharroo, R., Luis, J. F. , and Wobbe, F. : Generic Mapping Tools : Improved version released, EOS Trans. AGU, 94, pp. 409-410, 2013. 11 


\title{
THE EFFECT OF SEDIMENTARY BASINS AND ACCRETIONARY WEDGE \\ ON LONG PERIOD GROUND MOTIONS IN CHUKYO AREA
}

\author{
Sayo YAMADA*, Takashi HIRAI ${ }^{* *}$ and Nobuo FUKUWA *** \\ * Former Grad. School of Environmental Studies, Nagoya Univ., M. Eng. (Shimizu Corporation in present) \\ ** Assist. Prof., Grad. School of Environmental Studies, Nagoya Univ., Dr. Eng. \\ *** Prof., Disaster Mitigation Research Center, Nagoya Univ., Dr. Eng.
}

Long-period seismic waves are affected by the propagation path, and have a different nature depending on the source location. In addition to the accretionary wedge and sedimentary basins could affect the long-period seismic waves. The characteristics of ground motions on the irregular sedimentary basin structure vary depending on the incident direction of the seismic wave and the type of incident seismic wave. Therefore it is important to focus on the source location, and to consider the path effect together with the effect of the sedimentary basin beneath the site.

In this study, the 3D finite difference analysis based on the reciprocity theorem is employed to clarify the path effect and the effect of the sedimentary basin beneath the site. In regard to the path effect, the accretionary wedge could decrease the specific periodic band of seismic waves, in contrast to the Niigata sedimentary basin which could amplify the specific periodic band of seismic waves. In addition, the Kanto plain could so much not amplify the waves on the site in Chukyo area. In regard to the effect of the sedimentary basin beneath the site, the analysis confirm that the characteristic of ground motion fluctuates depending on the incident direction of seismic waves. Especially, the results of some observation points show that when the source located in a particular direction, the seismic wave is strongly amplified by the sedimentary basin

Specific amplification of seismic waves is examined by the numerical analysis of wave propagation using the simple soil structure models. As a result, it is revealed that the seismic waves are strongly amplified by the step of the layer near the site. Therefore, the ground motion at the site is amplified and the duration time is extended.

At last, amplifications of seismic wave radiated from sources of various directions are compared at the site on Chukyo sedimentary basin using the seismic ground motion records. The study revealed that the amplification of the seismic wave radiated from eastern sources is larger than other direction at the specific periodic band. The behavior similar to the result of numerical analysis is shown by the study using the seismic ground motion records.

According to the result that the effect of the wave propagation path and the sedimentary basin beneath the site varies with respect to the source location, the damage of specific long-period building could be large in specific cases of earthquakes. The examination of the ground motion using 3D finite difference analysis based on the reciprocity theorem is beneficial since the above mentioned effects are complicated and different around the earthquakes.

(2016 年 12 月 7 日原稿受理, 2017 年 4 月 24 日採用決定) 